\title{
5 The life of societies
}

In previous chapters, I have looked at a number of lives - of people, of objects, and of places. I started by thinking about individual people and what they were like, then the objects which inform us about them and their lives, and lastly the places in which they lived. Now I want to broaden my discussion out to encompass the whole environment that people knew, not so much physical as mental and ideological: the ways they interacted with each other, over short or long distances, how the communities within which they lived might have been structured, and how those communities lived together; not just communities at the local scale, but on the widest scale that might have existed in the period, in other words the Bronze Age "world". That means considering not just how large human groups were, and how many such groups might have lived in a given area or territory, but what the nature of their interactions was, peaceful or otherwise.

In this, it is probably easiest to detect those interactions which were not peaceful. Just as our news-filled world today is dominated by stories of violence and war, on the grounds that peace and normal life - when nothing special happens - is not newsworthy, so our view of the past is likely to be dominated by those occurrences which indicate something happened, something other than birth, reproduction and death.

In seeking to understand how ancient societies undertook and managed interactions, a range of types of evidence are available to us. Traditionally, archaeologists recognised interactions through the study of artefacts, which would indicate "trade", in other words the movement of raw materials or manufactured objects from one place to another. This movement would indicate that societies were in contact with one another, by means of travellers across short or long distances; it would show that some kind of economic and/or social interaction was taking place. The presence of objects made in one place and found in another relies partly on typological factors, partly on composition analysis; the importance of this method of proceeding has not diminished, but it has been supplemented in recent years by a still more powerful analytical tool: the use of ancient DNA and stable isotopes to determine the provenance and life history of buried individuals. A study of Bronze Age interactions thus has a range of types of evidence from which to work. Before considering the nature of interactions, therefore, some words about the specifics of movement - of people and objects - are necessary.

Ә OpenAccess. ( 2021 Harding, published by De Gruyter. (cc) BY-NC-ND This work is licensed under the Creative Commons Attribution-NonCommercial-NoDerivatives 4.0 License.

https://doi.org/10.1515/9783110705805-006 


\section{Movement of people and artefacts}

In an earlier chapter I talked about the increasing evidence for mobility, which is obviously newsworthy in an archaeological sense. Lack of mobility is also interesting, even if it would not be considered newsworthy by today's journalists. So while the information that the Egtved girl from Jutland moved about a lot during her lifetime suggests something important and even exciting (Frei et al. 2015), the recently published information that many British Beaker people stayed put throughout their lives, or at most moved within the same country or the same general area, is important to archaeologists but hardly news in a modern sense (Parker Pearson et al. 2016). So in this analysis, individuals from Northern Scotland, Yorkshire and the part of England known as the Peak District had relatively high mobility - 13 out of 68 individuals in Yorkshire, for instance, or 16 out of 68 for southern England; the largest proportion actually in northern Scotland at 63\% - , those in central England show little evidence for it (one individual out of 30; possibly more if isotopes other than strontium are considered) (Parker Pearson et al. 2016, 629 Table 1). Of course this "mobility" need not have been over long distances, merely over different geological and groundwater terrains, which might have been near or far. Nevertheless, the evidence published in 2016, and confirmed by other studies and for other periods, indicates that in the Beaker period a considerable number of people died in a place different from that where they were born and/or grew up (Price et al. 1998; 1994; Price et al. 2004). As analyses have continued, we know that more of this kind of evidence will be discovered, most notably with the recent demonstrations of more or less complete genetic replacement with the Beaker period, both in Britain (Olalde et al. 2018) and to a lesser extent in Iberia (Olalde et al. 2019).

\section{Personpower and population}

Mobility is of course interesting and important, and it supports the evidence of simple artefacts (of course artefacts are not simple, but they are mute - they cannot speak directly to us). As I discussed previously, it is beyond question that some objects moved over long distances; and commodities like copper or tin or salt also moved, of course not by themselves but by the actions of people. But within what social environment, or on what scale, or by whom, is another matter altogether. Was mining, for instance, a highly organised activity, involving considerable numbers of people, or was it a small-scale, home-grown affair, what in English we like to term a "two men and a dog" operation? It is hard to answer such questions in most cases, though it does seem clear that the 
scale of some of these operations must have been considerable. Zschocke and Preuschen, for instance, long ago made estimates about how many people would be needed for the extraction and processing of copper ore in the Mitterberg, part of the Bischofshofen mining district and how much copper would have been produced (Zschocke \& Preuschen 1932; Stöllner et al. 2011; Pernicka et al. 2016; Pittioni 1951). Figure 5.1, presenting figures taken from their work, shows that just for the Mitterberg scores of people would have been needed to keep three pits working; there are dozens of such pits in the area (though it is not known how many might have been open at one time, and since the shafts in question no longer exist it will not be possible to check). And this takes no account of the other areas of Austria that were extracting copper during the Bronze Age.

\begin{tabular}{|l|r|}
\hline Single opencast pit & \\
\hline Preparatory stage & 6 \\
\hline Production stage I & 14 \\
\hline Production stage II & 27 \\
\hline Final stage & 5 \\
\hline Subtotal & 52 \\
\hline
\end{tabular}

\begin{tabular}{|l|l|}
\hline Three opencast pits & \\
\hline Miners & 40 \\
\hline Timbermen & 60 \\
\hline Dressing ore & 20 \\
\hline Ore transport & 30 \\
\hline Miscellaneous transport & 10 \\
\hline Cattlemen & 10 \\
\hline Foremen & 10 \\
\hline & \\
\hline Total & 180 \\
\hline
\end{tabular}

Fig. 5.1: Labour estimates for the copper mining at the Mitterberg. Figures from Zschocke and Preuschen 1932. 
These figures are very considerable, and of course presuppose a high degree of organisation in the communities involved. Nowadays we are more conservative in our estimates, but even so, it is impossible to imagine that the Bischofshofen area can have been served by just a couple of dozen people. We have to imagine quite a big operation, even allowing for uncertainties over seasonality, duration of extraction, and so on. And incidentally, although the figure says "manpower", it should really say "person-power", as many of the shafts are too narrow for adults to get into, so children were involved; and if the situation at the Hallstatt salt mines is comparable, women as well as men were probably involved in the work.

I have considered the workforce necessary to mine salt in the part of Transylvania where Valeriu Kavruk and I have been lucky enough to find several major production sites (the most important, and the only one so far excavated, at Băile Figa, near Beclean on the river Someş), though since such estimates are speculative I have refrained from putting them into print. Although we cannot be specific, we imagine that the people actually working the rock face would have been relatively few compared to those needed to fell and transport timber, to work the wood into the necessary forms (large and elaborate troughs and many other smaller items), to arrange for a supply of fresh water, to collect and evaporate the rock salt produced in order to make crystalline salt, to collect the salt crystals thus produced and bag them up for transport; to say nothing of provisioning the workforce, keeping their tools sharp, and so on. The number of people involved could easily amount to several score, more if the transport of the salt to its eventual destination is included. If we just take one pit or shaft reaching down to the rock salt, it is likely that only one or two persons could have actually worked on the rock surface. This does depend, however, on what that process was: if, as has been shown to be the most likely, large wooden troughs were used, allowing fresh water to create depressions in the rock, then several people would be needed just to create a supply of water; once the depressions had been made, two or three people could then break up the rock surface. The supply of timber and water were crucial, to say nothing of the carpentry skills needed to create the troughs in the first place. Putting all this together, we doubt that much salt could have been produced without at least twenty workers on site plus at least as many in support roles, probably more.

Both for metal mining and for salt mining, there are implications for ownership and organisation, which are important but hard to assess (in areas where stone was used, this is potentially true for quarrying as well). It is unfortunate that so little is known of settlement in the immediate areas involved; this has led to the suggestion that the mining area was not a place of permanent settlement but rather one where people from different communities came, perhaps on 
a seasonal basis, to work the mineral for some weeks before returning to their home districts. In the absence of systematic survey work this must remain speculative. In the area around Băile Figa the known settlements lie within a few kilometres but no closer; one, at Coldău $5 \mathrm{~km}$ to the west, is a valley site on the river with an enclosing rampart on the landward side (Vlassa 1973); another, Dealul Bileag above Becleanut, is a hillfort on the north side of the river overlooking the whole area (Florea et al. 2007; 2008); excavation has produced Coţofeni and Dacian Iron Age material, but since little has been published it is unknown whether earlier material might also be present.

The numbers of people who would have been involved in other tasks is even harder to estimate (for instance building houses, erecting tumuli or cremation pyres, potting or smithing). Some scholars have made estimates on the basis of settlement and cemetery size.

\section{Settlement size}

In the previous chapter I talked about the life of the places where people lived, using the examples of Hungarian tells and co-eval lakeside settlements in the pre-Alpine zone. Thanks to the highly detailed information available from them, we can make good estimates of the number of contemporary houses, and the number of people who could potentially be accommodated in each. Of course the variability is very great when one looks at Europe as a whole, and the Bronze Age as a whole. We can point to times and places where individual farmsteads or hamlets were the norm, probably accommodating no more than a single nuclear family, and to others where large-scale sites suggest a complex form of social organisation. As I described, we can reconstruct a whole landscape in some areas where such farmsteads are scattered across an agricultural landscape; indeed, one might suppose this was the default situation. But individual farms do not get us far in reconstructing the bigger picture.

Let me again take three roughly co-eval sites, dating to the mid second millennium BC. Monkodonja in Istria, for instance, has been interpreted by its excavators as having a tripartite social structure (based on the tripartite form of the site) and a population of around 1000 (range 850-1240) (Hänsel et al. 2015, 482-6). For the tell site of Százhalombatta on the Danube in Hungary the excavators report that in its most intensively settled phase perhaps 150-200 houses might have existed at the same time, and if one supposes each housed five people, that would give a total population of 750-1000 (double that if there were as many as 10 people per house, which is not impossible) (Vicze 2013). A lakeside site such as the Forschner site on the Federseemoor was small- 
er (Billamboz et al. 2009); there are some 30 houses in the excavated part of the site, probably more than 50 in the site as a whole, which with five people per house would give a population of some 250. Lest you think that these are unreasonably large population sizes, one must recall that in the Late Neolithic Ukraine some settlements of the Tripyllja culture, such as Taljanky, covered hundreds of hectares and contained thousands of structures, with a population estimated at anything up to 15,000 (Müller et al. 2016). Of course there were many Bronze Age sites with much smaller population sizes, but it is these larger and more obvious ones that attract attention, not least because their system of social organisation becomes a matter of debate.

The problem for archaeologists is that such places do not usually tell us much about the organisation involved; Monkodonja may be an exception here, and it is certainly possible that its central area, on the highest point of the hill, the so-called acropolis, was home to an elite of some kind (Fig. 5.2). Much more can be deduced from graves, however; the usual assumption is that richer grave-goods bespeak richer and thus more powerful people. This has been extensively explored over the years by many scholars, so there is no call to discuss it here; rather, simply to stress that there are good grounds for believing that the marked difference between graves with many and rich goods, and those with few or none, has social implications. There can be other reasons as well, and the story is undoubtedly more complex than I am implying, but that would be another book.

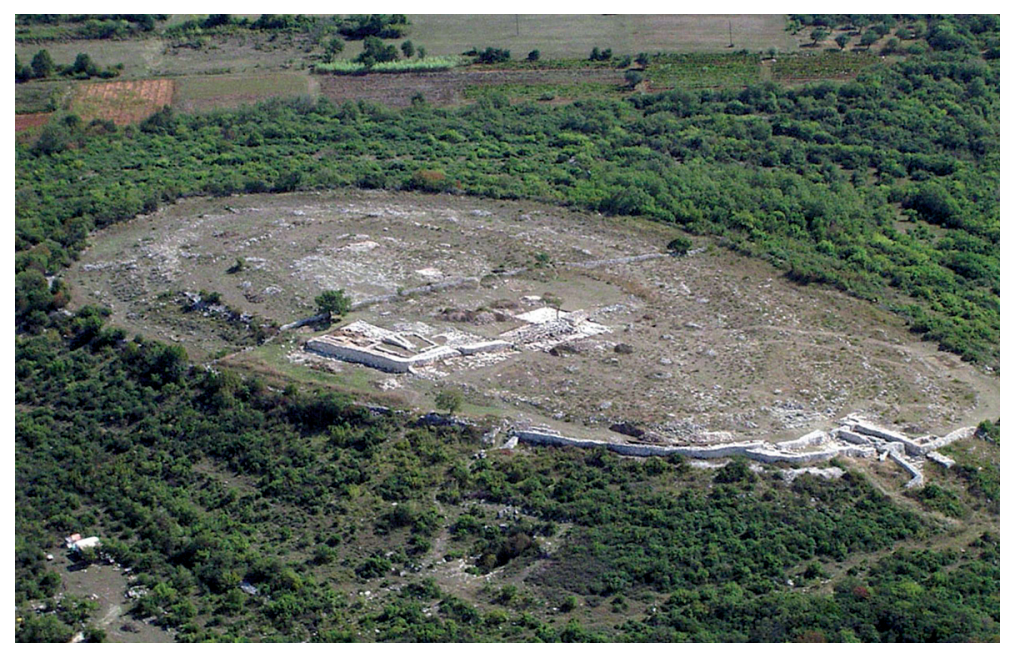

Fig. 5.2: Monkodonja, Rovinj, Croatia: aerial view of the site. Photo: Fran Hrzić, by kind permission of the Archaeological Museum of Istria. 


\section{Cemetery size as an indicator of population}

Here we enter an even more uncertain area of research. While it is true that we can tell how large some cemeteries were, where we can be sure that excavation has uncovered the whole site, in many cases the edges of such sites are disturbed and the number of missing burials unknown. Thus Nikulka's analysis concerned 370 cemeteries (of all periods) of which only 65 were completely excavated (Nikulka 2016, 168). The largest inhumation cemeteries, such as Franzhausen I or Gemeinlebarn F in Lower Austria, have several hundred burials, deposited over a period of several centuries. There are hundreds of such inhumation cemeteries in central Europe.

There are tens of thousands of barrows in western and northern Europe, though most only contain a few burials. Richard Atkinson attempted to reconstruct the population of Early Bronze Age Britain on the basis of numbers of barrows and the time over which they were constructed and used, arriving at an estimate of an average population of 2000 in the barrow-using areas (Atkinson 1972). Peter Fowler (1983, 34) suggested that while the figure could be considerably higher than that, it was unlikely to run into the hundreds of thousands, and was more likely around 10,000. Today, after many years of intensive survey and excavation, such estimates would be regarded as far too low; it would be dangerous to suggest even a tentative figure, but the intensive occupation of the landscape that fieldwork has demonstrated would certainly put the figure for Bronze Age Britain as a whole at least into the tens if not hundreds of thousands at any one time.

Such a scenario is easily compatible with estimates based on the numbers of cremated individuals in Urnfield cemeteries, for instance those of the Lausitz culture in eastern Germany and Poland. Hundreds of cemeteries are known, many containing hundreds of individuals; the period over which they were used is less than that of the Early Bronze Age barrows, perhaps 400 years or less. I have suggested in the past that the buried population of Late Bronze Age Poland alone must amount to several million. Dietmar-Wilfried Buck estimated a rising population from some 40,000 in Period II to around 120,000 in Period V for the area of the Lausitz and Billendorf cultures in Saxony (Buck 1997; Nikulka 2016, 194-5). A single cemetery probably served a relatively small area, perhaps just a single large settlement; this certainly appears to have been the case for the large cemetery at Sobiejuchy in the Pałuky area of Great Poland, close by the large fortified site discussed above (p. 76) (OstojaZagórski \& Strzałko 1982).

The size of a living population in a given society can be calculated from numbers obtained from the data in individual cemeteries. Nikulka has shown 
that these are very variable (Nikulka 2016, $168 \mathrm{ff}$, Abb. 17), from just a few people to 100 or more, potentially many more. Transferring such figures to a whole area introduces even more uncertainties. The conclusion has to be that any estimate of the overall population of a given area, such as a modern state, at a given time in the Bronze Age, is tentative in the extreme.

\section{Interactions, peaceful and warlike}

We know a lot about the form of the places where people lived, and believe we can make inferences from them about the size of the communities in which they lived and of which they were part; from their burials we can draw conclusions about a range of issues relating to beliefs and ideologies; but it is altogether harder to specify how groups behaved towards each other - unless, as was evidently sometimes the case, those relationships were hostile, resulting in aggressive action.

If that were the normal state of affairs, it would be a story of conflict, of a Hobbesian state of constant war between different groups of people. Now some scholars have made the case in recent years that war, or at least aggression, was the norm in parts of the prehistoric past, including the Bronze Age (Keeley 1996). There are indeed plentiful examples of sites where individuals seem to have died a violent death, but that is not quite the same thing as supposing that warfare was endemic to the communities involved. Indeed, there are many reasons to suppose that for most people life was essentially peaceful, or at any rate not warlike; there was a fruitful exchange of goods and people across wide areas of Europe, and beyond; the arts of peace thrived as well as those of war; and some people at least lived to a ripe old age (see chapter 2). Recent years have seen a dramatic increase in the evidence for the movement of both people and artefacts or raw materials across Europe. Nowhere is this more so than with those materials whose sources are restricted; tin and amber, for instance. In my opinion the most important single find of the Bronze Age in recent times has been the Uluburun shipwreck, with its extraordinary cargo of copper and tin, and hundreds of objects emanating from various parts of the east Mediterranean - as well as some from the central Mediterranean and even the Black Sea (Yalçın et al. 2005). As well as tin, the cargo included amber, of Baltic origin, and a host of other exotic objects. Almost as astonishing was another recent cargo find, off the town of Salcombe on the coast of southwest England: a cache of copper and tin ingots, along with gold and bronze artefacts including axes and swords (Needham et al. 2013; further finds from a different area of the coast off Salcombe are not yet fully published; Wang et 
al. 2016; 2018; Berger et al. forthcoming). There has been speculation about the tin sources used in the Bronze Age, as at other periods; and while this find does not rule out other sources, it provides strong confirmatory evidence that the tin of Devon and Cornwall was being shipped across the Channel to France and beyond (Berger et al. 2019). Another cargo find, at Langdon Bay off Dover, includes a range of artefacts, both local and continental (Needham et al. 2013, 23-56; 58-84) (Fig. 5.3). One object, published as a spear ferrule (Needham et al. 2013, 82-4 Fig. 3.18 no. 354), has been suggested by Thomas Koch-Waldner of Innsbruck University to be a socketed pick of "Mitterberger form" (Mayer 1977, 226 - 7, Taf. 90 -92), giving potentially interesting information about the distances over which objects travelled. ${ }^{1}$ And one must bear in mind that Dover is the site of a large (and probably complete) plank boat, which can only have been used to cross the Channel (Clark 2004).

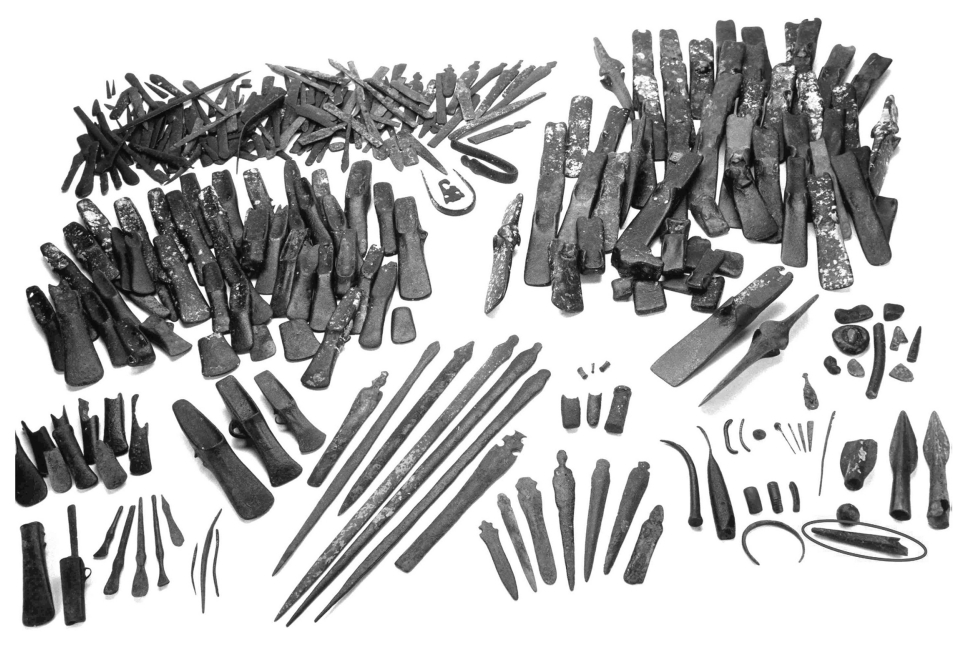

Fig. 5.3: The presumed cargo from Langdon Bay, near Dover. Source: Needham et al. 2013.

I mention these finds simply to act as an indicator of how communities were in touch with one another; not just communities in the same land area, but those separated by significant stretches of water. A boat like the Dover boat must have seated a crew of twenty or more (Fig. 5.4); it involved significant technological

1 The object does appear from the drawing, however, to be too slight to fit the criteria for such an object: Fig. 5.3, bottom right, circled. 
skill to make, and it may well indicate ownership on the part of someone; can we call that person a trader? Indeed, can we reconstruct the Europe of the Bronze Age as a place where craftsmen (whose presence is so clear) were joined by a group of people whose job it was to travel widely across the continent? All the evidence coming on stream now suggests that it was: there is strong evidence for a system of weights and weighing (Pare 1999; 2013; Rahmstorf 2006; 2010; 2016; Ialongo \& Rahmstorf 2019); analytical evidence shows how materials were widely distributed across the continent (e.g. amber, glass); and there are good analogies with what we know of the situation in the East Mediterranean, where records of various kinds indicate the frequent interactions between coastal cities (e.g. articles by H. Matthäus, H. Klengel and H. Genz in Yalçın et al. 2005). Sadly that evidence does not include the only part of Europe that was literate, Greece, since the Linear B tablets do not mention trade and traders at all. We do, of course, know a lot about the movement of goods and materials in the Minoan and Mycenaean world, most notably pottery, the source of which can be recognised stylistically but also through programmes of analysis (e.g. Jones et al. 2014 for pottery of Mycenaean type in Italy; many other articles cover this ground in Greece and the Near East). The question of the movement of copper is much-discussed (recent overviews: Earle et al. 2015; Radivojević et al. 2018); clearly those parts of Europe with no sources of their own needed to assure access to it, and there has been considerable success in pinning down the products of the Mitterberg area and Slovakia (Pernicka et al. 2016), as well as Cyprus. Recent work has also demonstrated that Sweden was an importer of copper during the Bronze Age, from a variety of sources including central Europe and Iberia, and - it is argued - Cyprus and Sardinia (Ling et al. 2013; Ling et al. 2014). This, if confirmed, would indeed be a remarkable demonstration that copper was moving right across the European continent; other scholars have, however, expressed doubt about such a movement (Pernicka et al. 2016, 41).

Mention of the Dover boat prompts me to recall all the other evidence for the technology of travel in Bronze Age Europe - over land as well as over water. The British plank-built boats of Dover type, previously best known from the examples from North Ferriby, East Yorkshire (Wright 1990), are a remarkable survival; the numerous depictions of boats on Scandinavian rock art show that they were very common, even though no example survives in corpore. What we assume are cargoes lost off shore or in river estuaries probably add to that evidence. On land, vehicles are mostly represented either by finds of wheels (initially in wood, later in bronze), or by models or what are believed to be cult vehicles (e.g. Strettweg, Steiermark, Austria: Egg 1996). Their very existence shows us that transport technology was highly developed in the Bronze Age; even if we lack paved roads (except for small sections that have survived by chance) it is possible to make as- 


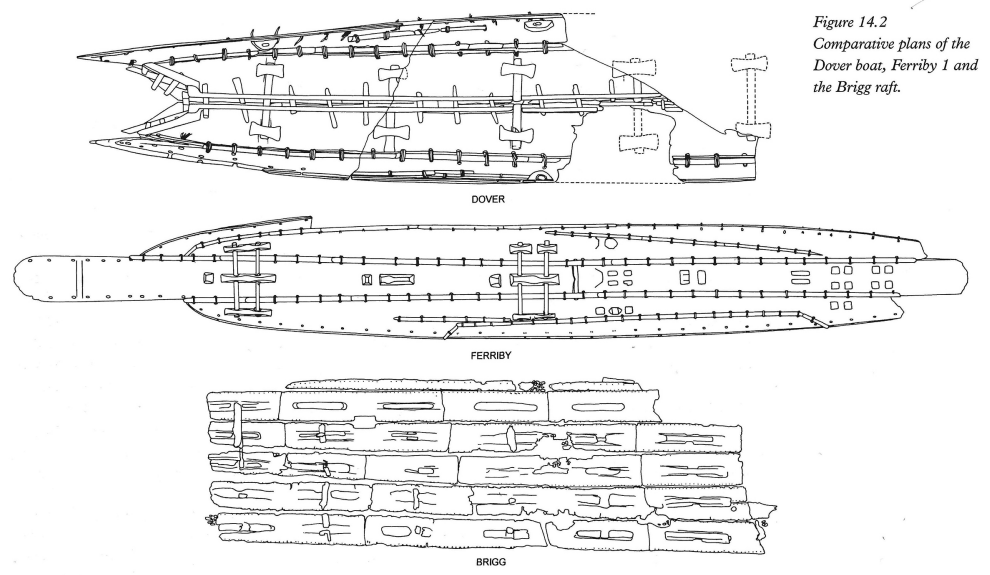

Fig. 5.4: British plank-built boats: Dover, North Ferriby, Brigg. Source: Wright in Clark 2004.

sumptions about ancient routeways by studying landforms and river valleys on the one hand, and the presence of artefacts along potential routes on the other.

If we can suppose, then, that Europe was a continent criss-crossed by trade routes, with traders and travellers conducting the movement, perhaps we can also assume that Europe was a peaceful place that enabled this trade to take place? Yes and no. Obviously people did successfully cross mountains and seas, so to that extent they lived in a peaceful world. But there is a darker side to the story as well. Many of the interactions between groups and societies were not peaceful at all. Much has been written in recent years about war and conflict in prehistoric societies. I think it is now possible to make a good argument for the type of warfare that was practised in later prehistory, and to sketch out a timeline over which conflict developed from a small-scale affair, involving a very few people, to a much larger and more deadly business (I presented my views in an earlier volume: Harding 2007, which proved acceptable to some but not all readers). Here one must make mention of the magnificent exhibition that took place in Halle (Saale) in 2015-16. The Halle team assembled much of the relevant information about prehistoric warfare, both in the exhibition and in the accompanying volume (Meller \& Schefzik 2015); their starting point was the mass grave uncovered in rescue excavations near Lützen and emanating from the famous battle of that name in 1632. Archaeologically speaking, there is no big difference between a battlefield of the Thirty Years War and a battlefield of the Bronze Age; both produce, in theory at least, the remains of the unfortunate individuals who lost their lives in the conflict, and sometimes the clothing 
and weapons they carried. In practice, of course, interpreting the remains of dead individuals from three or four thousand years ago as evidence of a battlefield is far from straightforward. Nevertheless, recent years have seen intriguing and on the whole convincing evidence for such conflicts.

Much attention has been paid to the ongoing work in the Tollense valley in Mecklenburg-Vorpommern, near the village of Weltzin and the small town of Altentreptow, in the Mecklenburgische Seenplatte district (Fig. 5.5). The published work so far mainly covers the research up to 2011 (Jantzen et al. 2011; Jantzen et al. 2014b; concise summary in Lidke et al. 2018); while more has been done since, partly documented in the Halle exhibition volume, these works give an excellent starting point for discussion of the significance of the area (one cannot really say "site", because the finds are strewn along a 2,5-km stretch of the river valley). ${ }^{2}$ Human bone material comes from the river bed (brought up by divers), from dredged material dumped on the river banks, and from in situ deposits beneath the dumped material and in the sections opened by erosion. The team have made a strong case for seeing this place as the site of a single battle.

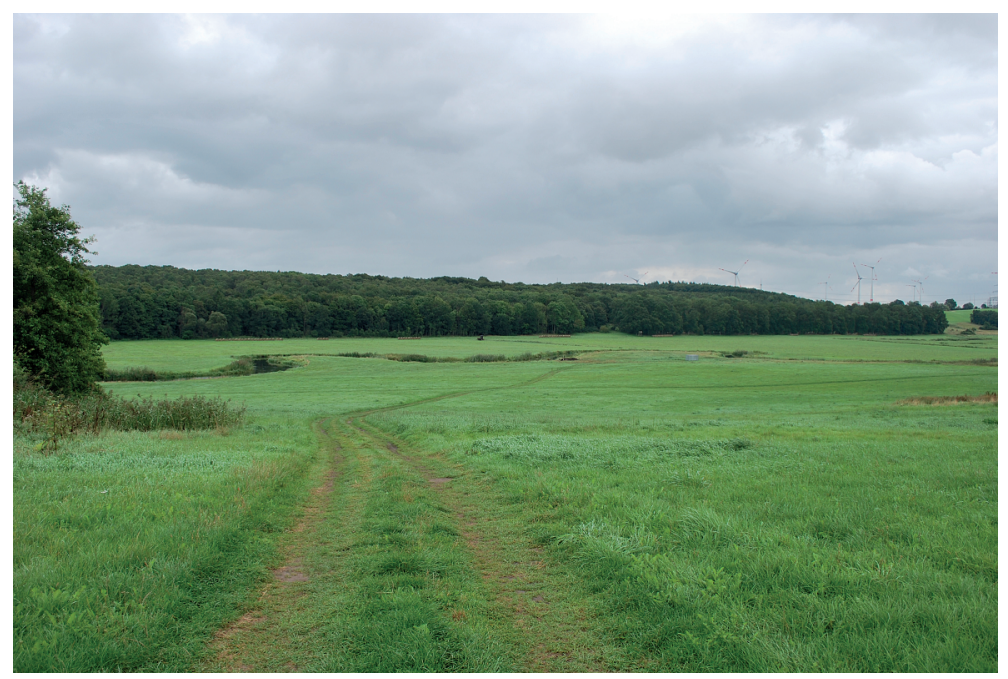

Fig. 5.5: The Tollense valley battle site in Mecklenburg-Vorpommern. Photo: author.

2 I visited in August 2014, and also attended a small symposium in Gross Raden in March 2011 which enabled me to see some of the finds, including those bones with the most evident signs of trauma. Grateful thanks to the excavators for inviting me and to Dr Gundula Lidke for guiding me round the site, supplying offprints, and checking these paragraphs for accuracy. 
Up to now some 12,000 human bones have been discovered, 8500 of them from a single findspot, Weltzin 20 (Brinker et al. 2014; Brinker et al. 2018); the minimum number of individuals represented there lies at 83; over the whole valley the number is 145 (Terberger et al. 2018). In some reports (Jantzen et al. 2014 (2017), 14), the density is given as one individual per $4.5 \mathrm{~m}^{2}$, with over 2000 individuals as possible participants in the violence. The bones show a predominance of male individuals, mainly young adults (age span roughly 18 to 35); a few were older and younger (including one young child). Four of the females were adults, one a teenager and one a child. The most important factor, however, concerns trauma on the bones. The most recent article on the human bones (Brinker et al. 2018) refers to 100 peri-mortem injuries, as well as a number of healed wounds (the latter is interesting in itself, as it shows that individuals were likely to be involved in aggressive action at different times of their lives). The authors point out that this frequency is far higher than one finds in cemeteries; and of course the figures take no account of wounds that left no trace on bone, hitting soft tissue instead, and just as likely to have been fatal. Large numbers of bronze and flint arrowheads were found, with one humerus having a flint arrowhead embedded in it (Flohr et al. 2015), and one skull having an embedded bronze arrowhead; these, along with the skull with a massive impact fracture, leave no room for doubt about the lethal violence that occurred here. As well as arrowheads, there is a smaller number of other weapons, including wooden clubs and a bronze palstave, not previously thought of as a weapon of war (Jantzen et al. 2014 (2017), 20 -21 Fig. 7). A causeway a little further south crossing the river at site Weltzin 13/Kessin 12 was considerably earlier in date; it is uncertain whether this was still in use at the time of the violence, but if it was, it might have been the place where a group of men was crossing when they were attacked; as they scattered, some went northwards and were shot or hit by clubs. Speculatively, the excavators suggest that there may be (or have been) between 400 and 1200 dead, with a potential for between 1000 and 6000 participants in the battle (Jantzen et al. 2014a).

The date of the events that occurred here, and their duration, are matters of the highest importance. The bronzes from the valley date predominantly to Period III. In the latest account, some 100 radiocarbon and seven dendro dates are discussed (Terberger \& Heinemeier 2014; Terberger et al. 2018). They begin in the $19^{\text {th }}$ century cal BC with the causeway at Weltzin13/Kessin 12; some centuries later, the path northwards was altered or another bridge constructed, to judge from a dendro date around $1320 \mathrm{BC}$, with further adjustments a century later. This, however, does not assist with the dating of the violence that followed. The excavators place strong reliance on two dates obtained from a skull with an embedded wooden arrowhead shaft (Terberger et al. 2018, 112 Abb. 13), 
both falling close to $3000 \mathrm{BP}$, and producing a calibrated combined date range of $1269-1208$ cal BC at $68.2 \%$ probability, or $1292-1158$ cal BC at $88.1 \%$, in other words most likely the $13^{\text {th }}$ century BC (the date for the bone is somewhat younger than that for the arrow shaft, but it seems highly unlikely that the two things refer to separate events). Wooden implements, including clubs, have a somewhat more diffuse dating, covering both the $14^{\text {th }}$ and $13^{\text {th }}$ centuries; the dates for the wooden shafts of 22 other arrowheads are said to concentrate in the earlier $13^{\text {th }}$ century, although the diagram illustrating this indicates considerable variation (Terberger et al. 2018, 114 Abb. 15).

One of the most remarkable results from the study of the site has been based on the isotope values of enamel from individuals on site Weltzin 20, which shows that two distinct groups of people are present, one of local origin, the other coming from some other area, which might include a wide area of northern Germany, or Bohemia (Price et al. 2017). The clear implication of this is that a battle occurred between local people and invaders; something that is suggested for a number of other sites but not (yet) demonstrated by independent means.

While I do not doubt the general interpretations that this was the site of significant fighting, in my opinion there are several points that suggest it was more than one simple battle between armed groups of young men. First, the age and sex profile is quite varied: there were a few women and children present, as well as older men (the females were identified predominantly through skull morphology; only one from the excavated area from the Os coxa). One presumably has to see these as camp followers caught up in the conflict and slaughtered as part of the fighting. ${ }^{3}$ Second, the bone material includes animal bone as well as human; only horse bones are connected with the "battle horizon", however, while cattle bones are a little later and not necessarily anything to do with the violence. Third, the dates are in fact quite varied, as the authors themselves point out (they have to stress potential systematic effects, such as old wood, fractionation, etc, in order to explain this). Previous accounts stated that two events were evident in the $13^{\text {th }}$ century BC (Terberger \& Heinemeier 2014, 114), but more recently obtained dates are more in line with the idea of a single event, which the most recent accounts emphasise.

If we simply take the dates from Weltzin site 20, it is quite evident that there is considerable divergence, even within the human bone group. If one includes the dates from the other sites along the river, the divergences are equally great.

3 Since at least one of the female bones has produced a widely different date from the bulk of the samples (Terberger \& Heinemeier 2014, Abb. 1), it is possible that the total number of females involved in the main period of conflict was even smaller than at first suggested (G. Lidke, pers. comm.). 
This makes one wonder about the viability of dating in these riverine contexts. If we look simply at Site 20 and exclude the anomalous dates, the picture is still not completely clear. On Fig. 5.6 I have calibrated the dates from human bone along the valley, as published by the team in 2014; I have excluded all those dates that are obviously anomalous (something that strictly one should not do). I have ordered them in the same way as in the plan from the publication (Terberger \& Heinemeier 2014, 102-3, Abb. 1-2), without making any assumption about the direction of deposition (in fact the scatter clearly supports the team's assertion that taphonomic factors have played a big part; the river has potentially moved material around, though not over any great distance; the disarticulation of bone is present even in the in situ deposits). Even so, it seems clear that no single date can be assumed for the "battle of Weltzin". We might well suppose that Site 32 is earlier than Sites 20 and 13; the other sites have a single date only, but Site 9 fits with Site 32, and Sites 4, 5, 12 and 21 with Sites 20 and 13. If we model the dates on this assumption, we get the outcome shown in Fig. 5.7. There is a fairly clear phase centred around 1200 cal BC; there is an earlier phase, which is not closely defined, and a single date from Site 17 which is clearly later. Dates on wood from Site 20 are rather scattered, but the two on weapons (a club and an arrowhead shaft, and the skull with embedded arrowhead, which one assumes would relate closely to the traumatised human bone) fall somewhat earlier than those on bone, perhaps because of an old wood effect.

My point in labouring the chronology here is to indicate that whatever one supposes happened in the Tollense valley in the Bronze Age, it was not one single event, but at least two, possibly more - though I recognise that the excavators have a different opinion. They have argued strongly against this suggestion (which I have not previously published), on several grounds: ${ }^{4}$ the consistency of the "battle horizon find layer"; the lack of animal gnawing on the bones, which one might expect if some had been lying around for anything more than a short time; the homogeneity of the bone depositions; the similar pattern to all the lesions (indicating sharp weapon trauma); the fact that the deposits lie in a boggy area, suggesting that a group of defenders had been driven away from the fighting area, and killed in groups; the similar composition of the bronze arrowheads from different parts of the site; and the similar diet of the individuals studied. Clearly these are all circumstantial arguments which should be considered as part of the overall scenario. The evidence of the radiocarbon dates suggests something different, in my view.

4 I am very grateful to Dr Gundula Lidke for her comments on a previous version of this section, arguing strongly for a single event. She is in no way implicated in my interpretation of the dates. 


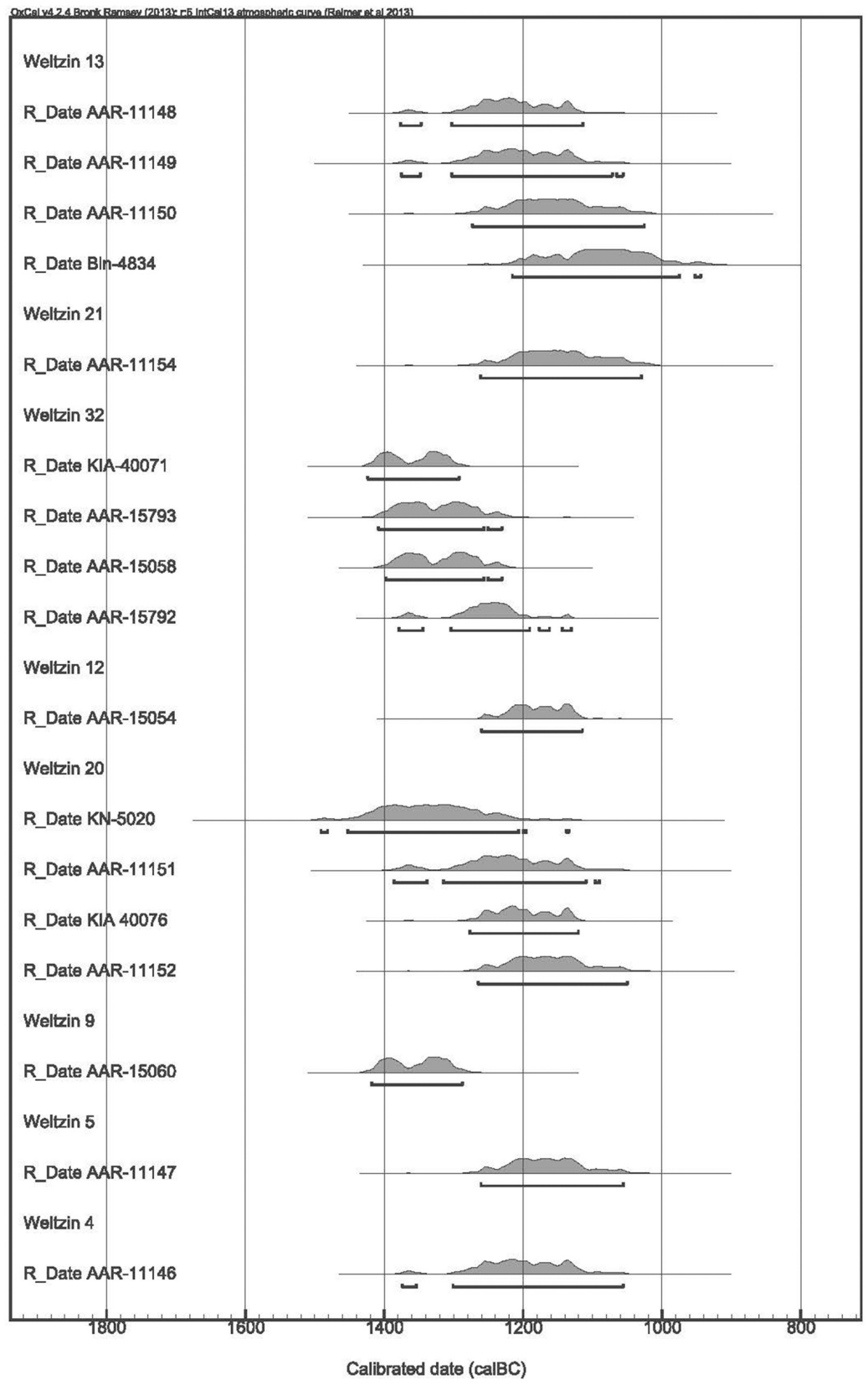

Fig. 5.6: Calibrated radiocarbon dates for the Tollense valley sites, arranged by site from south to north. Data from Terberger et al. 2018. 


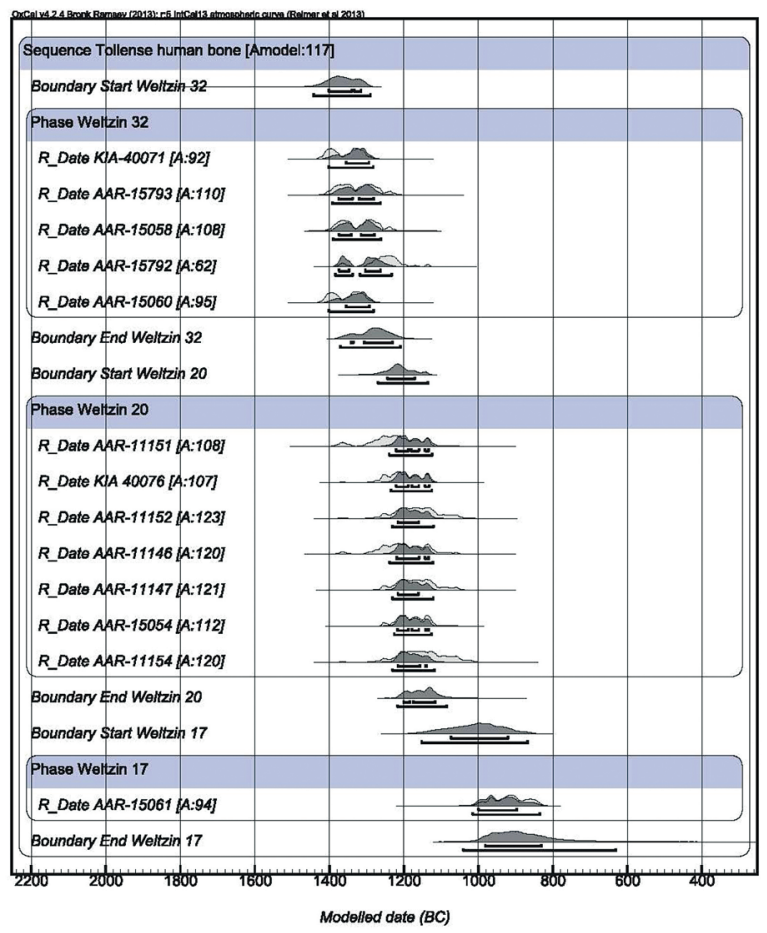

Fig. 5.7: Modelled radiocarbon dates for three of the Tollense valley sites, suggesting that there are at least two phases of deposition and therefore repeated history of violence.

This has implications for our understanding of group aggression in the period, and it leads me on to consider a site that I believe is most similar in many respects to the Tollense valley: Velim in east-central Bohemia. ${ }^{5}$ A comparison between the two sites is not altogether easy because of their very different situation and excavation history, and the fact that only a relatively small amount of the Velim site has been fully excavated and an even smaller part studied and published in detail (Hrala et al. 2000; Harding et al. 2007). Nevertheless, the parallels are striking, in terms of the human bone and its treatment. The site at Velim lies on a low hill above the flood plain of the Labe (Elbe) river (Fig. 5.8); ditch and pit circuits were filled with human bone and other material; the humans were generally thrown into the pits in disorder, without grave

5 Unfortunately the site was not even mentioned in the Halle exhibition, but the Tollense team is well aware of it: Price et al. 2017. 
goods, many bodies in single spots; in some places there were also cult practices in evidence, like the collecting up and deposition of crania. As at the Tollense sites, numbers of bones had indications of trauma, some clearly from weapon blows. Depending on one's view of the length of the Tollense violence, the fact that the deposition at Velim took place in a number of episodes may be comparable; some of the pits are large and deep, with whole or partial skeletons deposited at different levels (Fig. 5.9). Highly significant is the finding in the Czech excavations of large numbers of arrowheads, indicating an attack involving volleys of arrows (Hrala et al. 2000, 255 Fig. VII.20). It is not easy to interpret the findings; on stratigraphical grounds it seems clear that the events that led to the deposition of the human bone took place over a period of time, while there are other features that do not seem relevant to the notion of a massacre site. Nevertheless it is perfectly obvious that major violence occurred on this hilltop, perhaps over a period of time, but perhaps also with one major episode of violent activity.

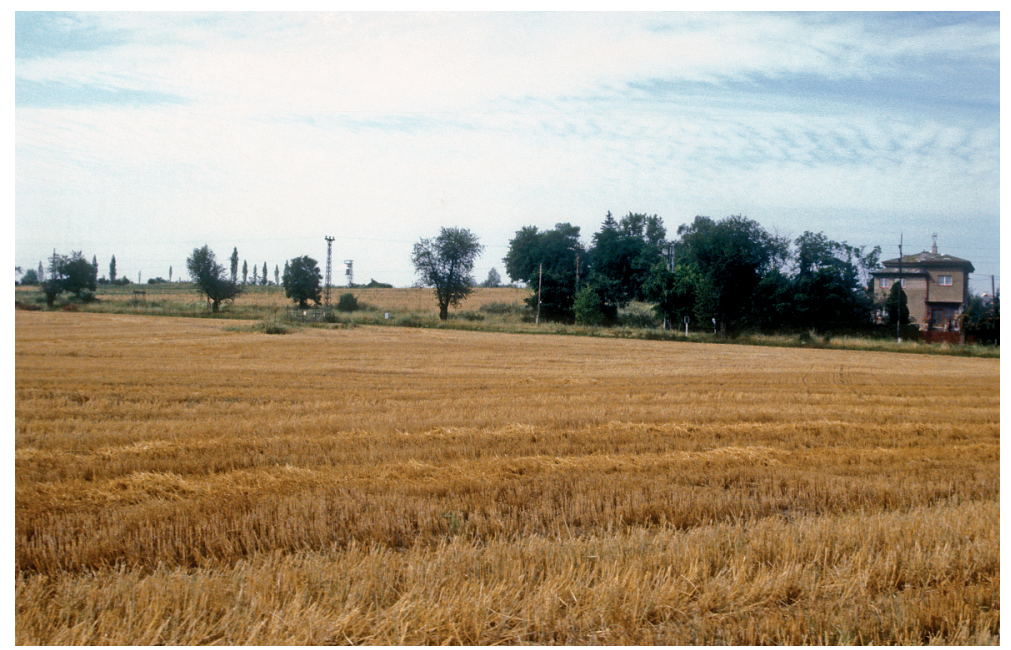

Fig. 5.8: Velim, near Kolín, east-central Bohemia; view of the site. Photo: author.

The chronology is known in some detail; the finds (including pottery of "Velim type") indicate a date at the end of the Middle Bronze Age and the transition to the Late Bronze Age (Urnfield period), usually seen as a time of major change. At the time of the excavations in the 1990s, only five radiocarbon dates were obtained from Velim (plus one from the Czech excavations, with a very wide error term), none on bone, and most indicating a date in or near the $14^{\text {th }}$ century cal BC (Hrala et al. 2000, 265; Harding et al. 2007, 83-4); two dates were on 


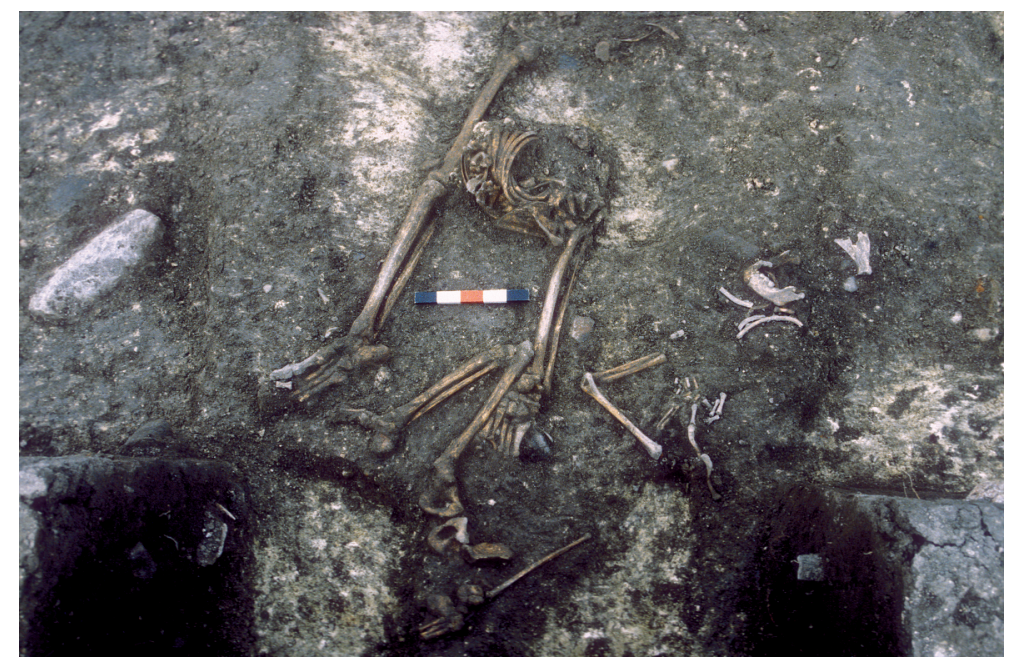

Fig. 5.9: Bone deposits at Velim. Photo: author.

carbonised grain, which might be expected to give relevant dates (3160 and 3125 $\pm 20 \mathrm{BP}$, both lying in the decades around $1400 \mathrm{cal} \mathrm{BC}$ ). This has since been massively enhanced by a big programme of investigation by Dr Dalia Pokutta (Stockholm); at the time of writing 53 further dates have been obtained, all on bone. Leaving aside one date which is much later (Iron Age), the remainder fall across a range from 3145 to $2873 \mathrm{BP}(1499-1379$ cal BC at $83 \%$ probability to $1131-928$ cal BC at $91 \%$ probability), centring around $3050-3000 \mathrm{BP}$, most likely the $13^{\text {th }}$ century cal BC (and thus close to the dates obtained on carbonised grain) (Fig. 5.10). A closer look suggests that one group falls in the $14^{\text {th }}$ and one in the $13^{\text {th }}$ centuries cal BC, but because of the flatness of the calibration curve in this period it is not possible to tie the dates down to single events.

This suggests that the events in the Tollense valley and at Velim occurred quite close together in time, even if one cannot say they were directly connected. In this context, it is necessary to recall that the date of 1300 was specified by Hermann Müller-Karpe (1959) as the start of phase Br D, the beginning of the Urnfield period, and though subsequent analyses have suggested this should go somewhat earlier (Della Casa \& Fischer 1997), the date of 1300 BC has remained in the literature as the accepted one. In fact dates for the Tumulus Bronze Age now appear to confirm that the period may have ended significantly earlier than 1300 BC (Müller \& Lohrke 2009 (2011)). Other discussions, relating to other parts of central and south-central Europe, suggest the same thing (e.g. Capuzzo et al. 2014; Capuzzo \& Barceló 2015), though there are still too few radio- 


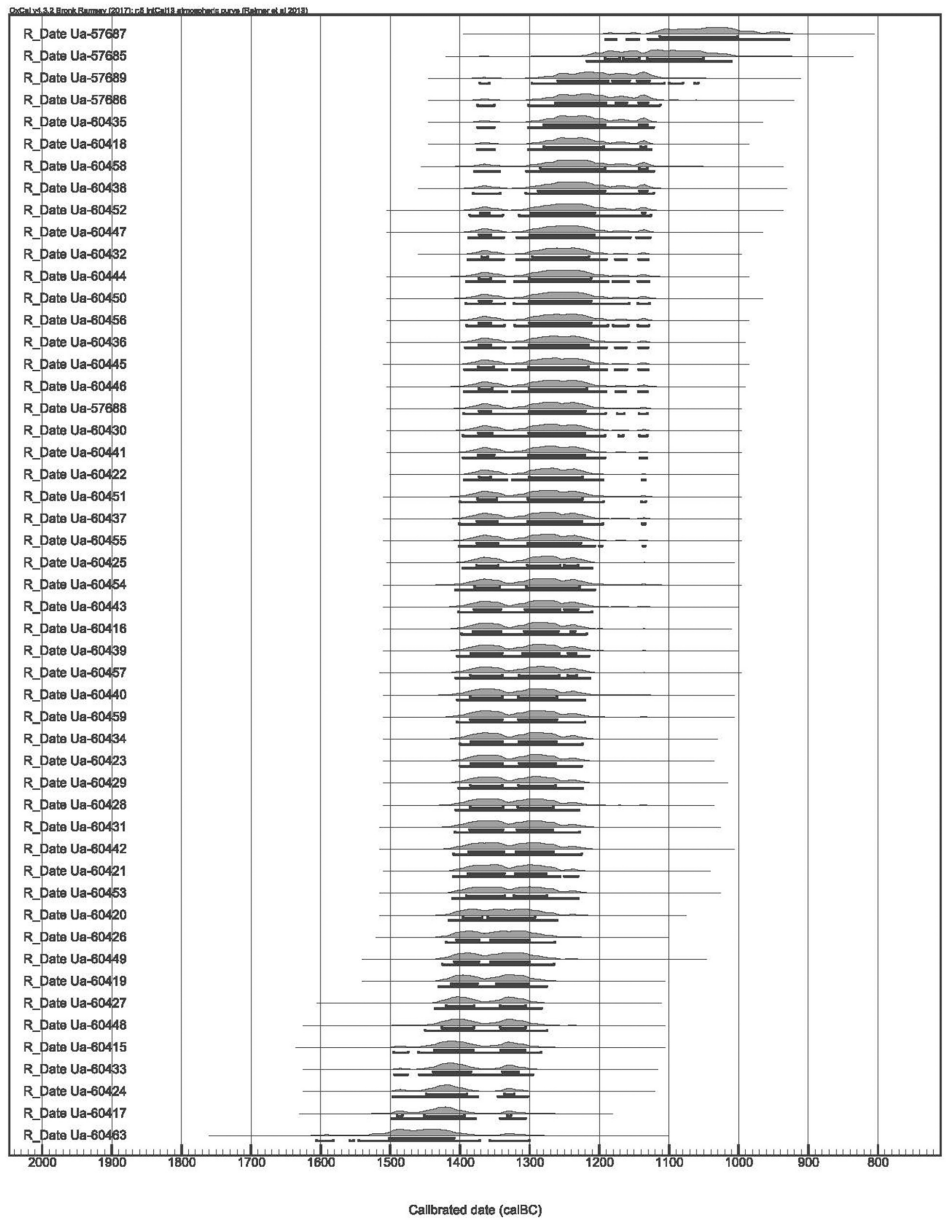

Fig. 5.10: Radiocarbon dates for Velim, showing calibrated range of all available dates on bone from the site. Samples taken by Dr Dalia A. Pokutta (Stockholm) from the material collected by the author, and dated by Göran Possnert and Lars Beckel of the Uppsala Ångström Laboratory.

carbon dates on classic Tumulus period graves in Germany for complete certainty in the matter.

The point about my labouring the chronology is that it has long been recognised that the start of the Urnfield period marked a big change in cultural phenomena across Europe as a whole, and in central and south-eastern Europe in particular. Several scholars, notably Wolfgang Kimmig (1964), observed that this period was one of major upheavals in the Bronze Age world, possibly 
even to be connected with events in the Mediterranean (notably the Sea Peoples, known from Egyptian monuments). Some have supposed that we are witnessing an influx of new people at the time, responsible for the changes in burial type cremation - that appear with the arrival of the new artefact types. Since it is now evident that violence was being practised on a large scale in central Europe at just this time (the $14^{\text {th }}$ and $13^{\text {th }}$ centuries), the case is even stronger. ${ }^{6}$

Other Bronze Age sites include evidence for trauma on or weapons embedded in human bone, such as a young male from Tormarton, Gloucestershire (Osgood 2006), a skeleton with embedded arrowhead from Klings, Thuringia (Feustel 1958, 8, 84-85, Taf. XXXII; Cornelius \& Pescheck 1958), or the remarkable assemblage in a pit at Cliffs End Farm, Kent (McKinley et al. 2014, 37-52, Plate 2.3, Fig. 2.16; 120-124, Plates 4.6-4.8); at this site an elderly female showed sharp weapon trauma on the skull. A male Beaker burial from Barrow Hills, Radley, Oxfordshire, was accompanied by a damaged barbed and tanged arrowhead in the spinal area, which the excavators say "may have been the cause of death" (Barclay \& Halpin 1999, 140). Weapons are a major part of the material culture of the Bronze Age. None of these pieces of evidence, however, on their own provides the unequivocal evidence that one ideally wishes to have in constructing a picture of Bronze Age warfare. Probably the best example of a set of people who both used and suffered from aggressive activities in the Bronze Age is represented by the remarkable cemetery at Olmo di Nogara in the Po valley (Salzani 2005). Here, in a cemetery of over 500 graves (the majority by inhumation), 43 contained swords, extending over all three phases of the site (the last represented by a single example). Furthermore, a number of the dead had traumatic injuries on their bones, including cutmarks and fractures (Canci et al. 2015; Canci et al. 2009). The excavators have understandably interpreted the site as being the resting-place of a group of warriors, with obvious implications for society as a whole (Cupitò \& Leonardi 2005a; 2005b). This cemetery dates close in time to Velim (Italian Middle Bronze Age 3 to Late Bronze Age 1) and thus arguably part of the same phenomenon.

But one can use these types of evidence in a fruitful way to create a scenario that in my opinion is as good as any other. First we have to accept that warriors became an everyday part of Bronze Age life; the dagger changed from being a weapon used primarily in hunting to one marking out warriors; and with the invention of the sword, perhaps too the bronze spear, one has the first clear evi-

6 The ERC-funded project led by Dr Barry Molloy (Dublin), "The Fall of 1200BC: The role of migration and conflict in social crises at end of the Bronze Age in south-eastern Europe", will no doubt shed light on these matters. 
dence that weapons were intended for use against other humans, not just against animals.

\section{Forts and territories}

The other factor of note is the rise of fortified sites. Fortifications were not, of course, new in the Bronze Age; they were present in the Neolithic, sometimes in quite sophisticated form. But in the Bronze Age they are both more complex in construction and appear in many areas (Burgenbau 1982). In some well-studied areas, they arguably lie at the centre of territorial units, as with many cases from different parts of Europe. In the Romanian Banat, for instance, the huge site of Corneşti-Iarcuri (jud. Timiş) is of particular importance because of its extraordinary size (Szentmiklosi et al. 2011; Heeb et al. 2017) (Fig. 5.11). It should not be seen as an isolated site, however: it lies in an area containing many other fortified sites, notably Sântana near Arad (Gogâltan \& Sava 2010), with others across the border in Hungary and Serbia. The same is probably true for central and southern Germany, where several authors have chronicled multiple sites in defined areas, such as Württemberg (Biel 1987) or Hesse (Jockenhövel 1980). In Britain and Ireland they are also sometimes associated with long-distance earthworks that served to divide up large chunks of land - estates or perhaps something more like tribal territories (Gingell 1992; Grogan 2005). In a quasi-territorial pattern like this, it is highly plausible to see the sites as central places in territories; and this leads me to think that the type of warfare involved is essentially one based on raiding.

\section{Type of warfare}

And this brings with it further implications relating to the social structure involved. The concept of Gefolgschaft, as known from early medieval times, is familiar (Landolt et al. 1997; Steuer 2006), as is the belief that this type of structure goes back to the early Germanic tribes as described by Tacitus, where the chieftain and his retinue or comitatus was the type of social organisation through which warfare was conducted (Germania 13:2-3, 14.1). I cannot of course prove that this went back as far as the Bronze Age, but I believe it is highly likely that it did; while material culture may develop and differ over the thousand years involved, the pattern of fortified sites strongly suggests that raiding was the predominant type of aggressive activity involved. 


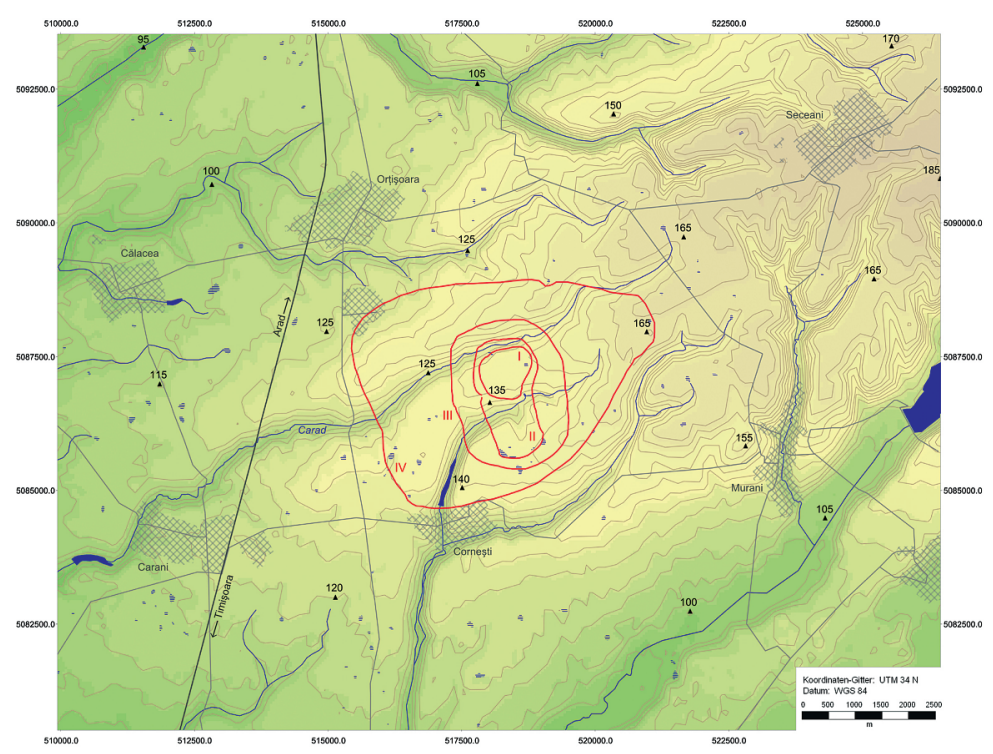

Fig. 5.11: Cornesti-larcuri, near Timişoara, Romania: plan of the multi-circuit site in relation to the local topography. Courtesy of Bernhard Heeb, Berlin.

Arguably Velim and Tollense indicate just such a situation: repeated phases of raiding, in these instances clearly successful, but no doubt at other times not. At present we do not know much about the local communities in either place who might have been involved in these altercations; we have to rely on contemporary evidence from other sites, of the kind I have outlined earlier. But I believe we would not be far wrong if we went along the lines of the comitatus system I have mentioned, and supposed that groups of young men, numbering in the scores or low hundreds, and serving the interests of a princeps or local chief, conducted these raids.

If one wants to look to ethnography for parallels for such activities, I believe one need look no further than the presentation of Dani warfare in West Irian (Heider 1997; 1972), as shown in the famous film Dead Birds (1963). Not every aspect of this work is strictly correct, as various commentators have pointed out (Kirsch 2010), but the general picture is one that seems to concur remarkably with what one could believe of Bronze Age warfare. Conflicts were usually over pigs and women, much less often over land rights; before engaging in attack, support would be sought from other groups, in order to create a confederation (political unit) of allies. When it came to hostilities, these might go on for long periods, though the actual fighting was sporadic and might only last a few 
hours on a given day. Tall watchtowers were built to guard against sneak attacks; the fighting itself consisted of formal battles in designated areas, as well as in surprise raids. Preparations were elaborate, involving preparing the body with grease and furs, and donning special feather headdresses. Usually there would be less than 200 men on each side. When the fighting started, first of all insults would be traded, then the sides would move within arrow range, more rarely spear range, when long spears might be thrown. The actual fighting typically lasted only 10 - 15 minutes at one time, with 10 - 20 such clashes in a day's fighting; encounters were bloody but fatalities rare - each side would typically end the day with a few wounded warriors. And if it rained, battle would be postponed in order not to spoil the feathers and furs.

Of course this picture, even if accurate for recent groups, cannot be applied directly to what we can reconstruct of Bronze Age fighting, but it does chime well with what we can see in the archaeological record, and reconstruct on the basis of accounts in the Roman authors. It suggests that aggression between groups was a constant of life, even if not a frequent cause of death; and to my mind the sequence seen in the third and particularly the second and early first millennia BC suggests just such a scenario, especially when defended sites become common around $1200 \mathrm{BC}$.

In this context, a recent attempt by Harald Meller to promote the idea that there were "armies" in the Early Bronze Age must be mentioned (Meller 2015). The justification for this idea comes from the varying contents of graves and hoards, in particular the difference between rich graves containing daggers, and hoards with varying - sometimes very large - numbers of flanged axes; he contrasts the 1174 axes with the 36 halberds, 30 daggers and 11 double axes from Early Bronze Age finds in Middle Germany. Meller sees the numbers of axes as modular $(30,45,60,90,120$ - with 300 in the case of Gröbers-Bennewitz). This modularity would, in his view, represent units of fighters, so for 30 axe-bearers there would be one halberd-bearer, for 60 axe-bearers a dagger-bearer, and so on (the basic unit being 15 axes/fighters). These figures might then compare with the situation in the Roman, or indeed the Prussian army.

Intriguing though this suggestion is, it depends on the view that axes were used as weapons, and that the hoards of axes were deposited at some stage as some kind of representation of an army. The obvious problem is that hoard deposition is a highly complex matter, in which personal ownership of individual items is hard to accept. Many writers have wrestled with the question of the meaning and function of Bronze Age hoards; Meller's idea is certainly different, but unlikely to find wide acceptance. It is noteworthy that other authors have attempted similar reconstructions on the basis of hoard finds: Randsborg for the hoard of Smørumovre, Zealand (Randsborg 1995), while attempting to apply a 
similar methodology to the Hjortspring boat, and Kristiansen for hoards from Hungary (Kristiansen 1999). Influential though all these authors are, the interpretations remain far from conclusive.

\section{The wider world: interconnections and systems}

When we look at various parts of Europe where networks of forts arose in the later centuries of the second millennium BC, we are in my view justified in interpreting them in just such a manner as the Dani example suggests. But this leads me on to consider wider issues of how societies interacted, not just on this local level. Here, the use of World Systems Theory has been particularly influential; so much so that the smaller details of local sites and artefacts have been dangerously ignored.

A danger in prehistoric archaeology, and to some extent also in the archaeology of later periods, is the temptation to over-interpret the data. While it might not be fair to say you can interpret prehistoric material to conclude whatever you want, it is certainly the case that some scholars have been guilty of selective treatment of the data. I am not sure that even now the time is right to make a full assessment of the situation, but things have changed markedly in recent years, partly through new finds, and partly through new analytical techniques which were not dreamt of when World Systems Theory started being employed in archaeology. In the first chapter I pointed to some of the finds which have changed the situation so markedly: the Uluburun shipwreck of course, but also the other cargo finds I mentioned earlier, the evidence for major Mycenaeanising sites in Italy, gold cups akin to those from Rillaton and Fritzdorf in south-east England and northern Italy, and many other individual finds from around Europe (not to speak of the Nebra disc). Of course things have not stood still in the East Mediterranean either; for instance the recent discovery of what is interpreted as a Mycenaean palace at Ayios Vasileios near Sparta, with Linear B tablets and other remarkable finds (https://popular-archaeology.com/article/lost-and-found-the-mycenaean-palaceof-laconia/, consulted 20 September 2018).

Then there is the evidence from stable isotope and DNA studies, which shows both the movement of people and animals, in some cases apparently over considerable distances, and aspects of diet; analytical work on copper, tin and gold, also suggesting long-distance movement of raw materials; and much else.

In fact there is now no doubt at all that the world of Bronze Age Europe was a highly interconnected one. I mentioned the well-known Balkåkra drum in a previous chapter. Each year brings new information. Recent years have brought 
news that the composition of glass beads in Denmark suggests a match to that of Egyptian and Mesopotamian glass (Varberg et al. 2015; Varberg et al. 2016); this joins earlier evidence that a glass bead from Wilsford in southern England has a composition akin to East Mediterranean ones (Henderson 1988; Guido et al. 1984), while other work has shown that a number of composition types were around, including one at home in north Italy and known especially from a much discussed but so far only partly published site at Frattesina in the Po valley near Rovigo (Towle et al. 2001; Angelini et al. 2004). This place is of the highest importance, as it was clearly a major production and trading site, with working in metal, glass, amber, ivory, stone and several other materials taking place; and as I mentioned before, among the amber types produced (here possibly, or certainly at the nearby site of Campestrin di Grignano: Bellintani et al. 2015) were the beads of Tiryns and Allumiere type, which were widely exported and even found their way to kurgans in distant Ukraine (Berezanskaja \& Kločko 1998) (Fig. 5.12). We know that Frattesina was far from alone in the lower Po valley; recent work by teams from Padova University have explored the site of Fondo Paviani not far away in Legnago district where blue glass has also been found (Cupitò \& Leonardi 2010); while other sites in various parts of Italy have also produced glass of East Mediterranean (including Mycenaean) composition (Bellintani et al. 2006; Bellintani 2011).

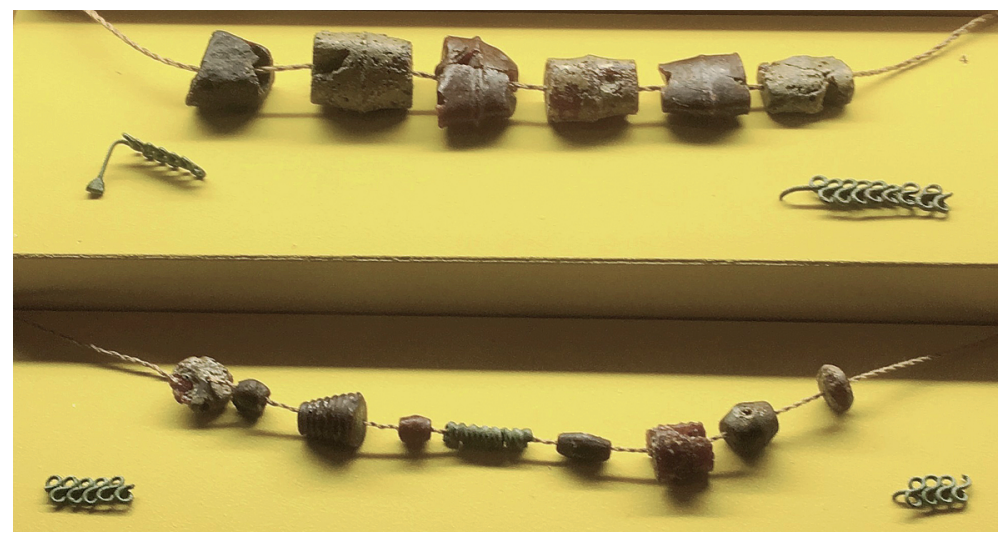

Fig. 5.12: Beads of Tiryns type (above) and Allumiere type (below, third from left and third from right) from Frattesina. Photo: author.

This is not the place to give details of recent work on the movement of metals; as mentioned above, the analyses by Ling and colleagues indicate that Sweden derived its copper from almost everywhere except Sweden (Ling et al. 2013; 
Ling et al. 2014), with the intriguing if controversial suggestion that oxhide ingots are depicted on rock art (Ling \& Stos-Gale 2015); and the finding of physical oxhide ingots far from their Mediterranean home is especially telling, notably those in southern Germany (Primas \& Pernicka 1998) but also in countries bordering the Black Sea (Leshtakov 2007; Doncheva 2012; Harmankaya 1995; Schuster 2005; Giumlia-Mair 2008-2009 (2011); Rotea 2002-2003 (2004)); to say nothing of their spread throughout the central and western Mediterranean (Lo Schiavo et al. 2009).

In other words, the evidence shows us that there is no question Europe in the Bronze Age was highly interconnected. Whether one chooses to impose a model on this interconnection that involves systems is probably a matter of choice. For my part, I am content to chronicle the connections - whether from artefacts (Chapter 3) or from people (Chapter 2) - and leave higher orders of interpretation on one side, pending a fuller understanding of the material.

\section{Society and economy}

This brings me to some words about recent discussions on the nature of society and economy in Bronze Age Europe, and in particular the concept of the "political economy" as applied to that time and place. This concept has been developed principally by Timothy Earle, usually in collaboration with Kristian Kristiansen (Earle 1997; 2002). What Earle means by this term seems to be something bound up with trade (particularly in copper), the availability of the new materials, and the "nature of property relationships by which local corporate ownership was individualized and extended over places and things critical for the emergent international metal trade" (Earle et al. 2015). In this view, it was control of riverine routes through which trade passed that was crucial; but there were changes in the treatment of the land too: the new pattern of farms and barrows which Earle and collaborators imagine to have "materialized a new property system based on farms with larger and more long-lasting buildings". Such control would also include that over the land producing local commodities; and it implies an integrated system of trade across Europe. Commodity chains might then develop, and control of them would centre on pinch-points or "bottlenecks", that is, places through which the trade had to pass, and which could relatively easily be controlled by local elites, but also technological skills such as were needed to build wagons or, more especially, boats. And furthermore, such control would need to be policed, in other words force deriving from martial equipment and warriorhood would need to be applied (just as in the Viking period trade was accompanied by force when necessary). 
Earle and Kristiansen have developed these ideas further, mainly in response to a critique from Tobias Kienlin which denied that the Bronze Age was qualitatively different from the Neolithic, at least as far as tell communities in the Hungarian Plain were concerned (Kienlin 2015; 2012; Kristiansen \& Earle 2015). Setting aside the combative language employed, Earle and Kristiansen's main argument is that the Bronze Age saw a critical difference from the Neolithic, in that it shows changes in settlement patterns (in the areas they have themselves worked in), and - crucially - the introduction of an international trade, in metals and "other wealth items", which, through the introduction of "foreign wealth", would have "transformed the political structure and identity in the society” (Kristiansen \& Earle 2015, 241).

In practice I think this is largely a manufactured controversy, more to do with different approaches to archaeological data (and perhaps also with a need to bolster academic egos) than with real divergences of opinion. Thus Kienlin concentrates on tell sites in an area he knows well, and sees the world that people lived in in generally local terms. Earle and Kristiansen, as is their habit, see the world in broad, highly generalised terms, preferring to cite their own team's specific work in Hungary (Earle \& Kristiansen 2010). What they bring to the discussion is an emphasis on interconnection and interaction - which no one would deny. In my opinion both approaches can be valid. I have in the past used local site maps to indicate how I think most people worked at the local level, for instance in the distribution of sites round Swiss lakes (Harding 2000, 423-4). People in such situations were inevitably concerned firstly with their immediate environment, the needs of subsistence and shelter; and secondly with the requirements of procurement from further afield, whether at their own instigation or the bidding of a superior.

We can pursue this local world further through recent work that takes a novel approach. Mads Kähler Holst from Aarhus and colleagues, for instance, have attempted to view a barrow landscape through a landscape approach, based on the need for sods and turves to construct the barrows, and the ensuing soil impoverishment which would follow repeated turf stripping (Kähler Holst et al. 2013) (Fig. 5.13). Particularly in the eastern part of this area, there was clearly a danger that agricultural land might become dangerously over-exploited by the end of Nordic Period II. Since the number of Bronze Age barrows in the relatively small country that is modern Denmark is conservatively estimated at 50,000, mainly constructed over a period of no more than 350 years, the implications are clear. I have suggested in the past that one can make use of barrow distributions, however, to indicate potential group or community territories (Harding 2000, Fig. 13.4); the same would be true for the Jutland example just cited. 


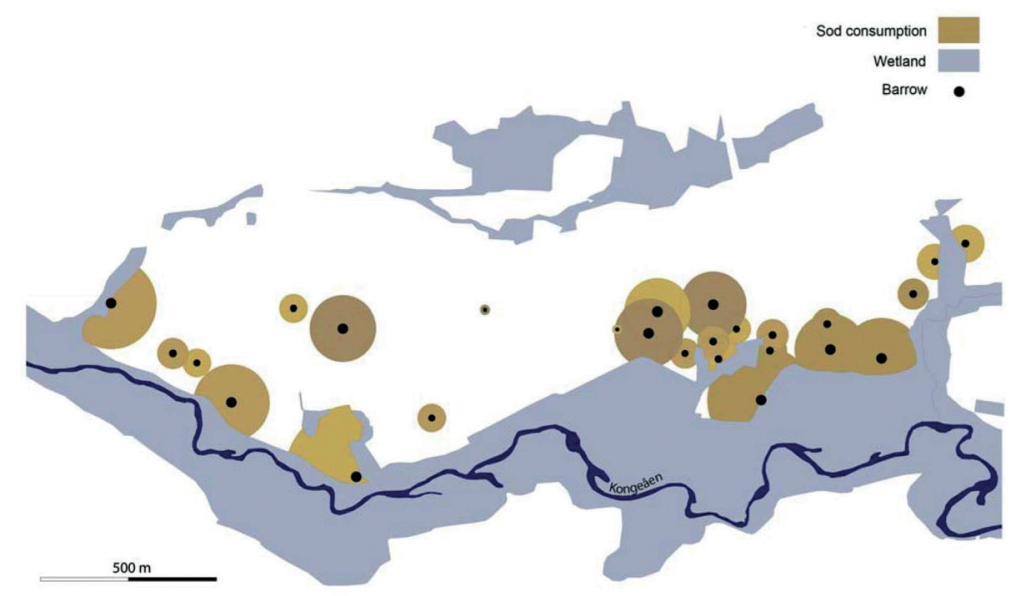

Fig. 5.13: A Danish barrow landscape, indicating the area from which turf and soil would need to be stripped for each barrow. Source: Kähler Holst et al. 2013.

\section{World Systems: a(nother) critique}

So far I have not mentioned a key work in promoting a new approach to the European Bronze Age, the book The Rise of Bronze Age Society (Kristiansen \& Larsson 2005). Since I have published critiques of this work and the basic concepts of World Systems Theory already (Harding 2006; 2013), I will simply confine myself to a few observations. The basic premise of the work, set out in the early pages, is that it is no good adopting a simple typological approach to the material culture of the past (such as I have adopted), for various reasons. In this analysis, we are told that the typological approach deprives material culture of any symbolic role as a medium of social or ritual meaning; the study of individual objects prevents a contextual or holistic overview and because of this the social significance of imitation is not recognised, or is denied. More mysteriously, we are told that to give "structured similarity (the type) less significance than selective differences (typological elements)" is a distorted approach (Kristiansen \& Larsson 2005, 19). Instead, we are urged to bring in textual evidence, and to bring back diffusion as a concept, by means of integrating certain theoretical and interpretational frameworks, but contextualizing it. This will involve consideration not only of the flow of goods and people, but also of the process of interpretation of interactions by focusing on institutions, not least by identifying them in material culture.

The dangers inherent in this approach seem all too evident. How can one validly use textual evidence in a preliterate period? How can one focus on insti- 
tutions when the evidence for them comes from later periods and different societal contexts? Why is "structured similarity" in artefact forms more important than "selective differences" (whatever that means)? To be cynical, it really means that one uses those artefacts that fit the pattern one wishes to see, and ignores the rest.

Twenty-five years ago (Harding 1993) I was sceptical about the idea of a farreaching Bronze Age "world", as it was then promoted by early adherents of a "world system" as applied to the ancient world, certainly the prehistoric world. The problem was that much was assumed on the basis of totally inadequate data, or misinterpreted information, sometimes based on little more than wishful thinking. But this did not stop this particular bandwagon from rolling into action, as more and more people jumped on, with little more propelling them than a desire to follow the leading exponents. I have considered this matter in print several times already and do not need to do more than outline the main aspects here (Harding 2013 with full bibliography). Two assumptions are paramount: first, that in a world system there are centres or core areas and peripheries; second, that there are cycles of boom and bust, rise and fall, flourishing and decline. Centres rely on peripheries to supply them with raw materials of various kinds; peripheries rely on centres to provide them with manufactured goods, but also - and this is crucial to the argument - to stimulate social and economic change.

While there are aspects of this model which can be considered useful, my personal opinion is that it is an imposition on the data rather than a faithful modelling of the actual evidence. It is easy to find fault with individual statements in Kristiansen and Larsson's book; rather, it is the overall idea of interconnection on which one must concentrate - and in this analysis, this means connections not just in physical material, but also in the ideological sphere, through institutions, social and economic. Interestingly, Kristiansen has in recent years moved towards a more evidence-based approach, largely through interaction with research groups working on DNA and isotope methods.

\section{Coda}

Can we then write a "history" of Bronze Age societies in a Bronze Age world? Should we even try? Twenty, or even ten years ago, I would have been sceptical about such a possibility. It is still true that we cannot describe in detail the life of a single Bronze Age person, or know her/his name, but since it is now possible to follow the life history of certain individuals in some detail, and to describe human groups in terms of autochthons and incomers, we are much closer to his- 
tory, sensu life description, than we were. Chris Gosden and Gary Lock (1998) discussed "prehistoric histories", by which they meant either "genealogical" history or "mythical" history - both kinds being ever present in the minds of people who lived prior to the use of writing and written records. For them, what their parents and grandparents - and earlier generations - did was of paramount importance. And they will have told stories about events and persons from the past, who maintained an importance for generations present and future. The landscape is a crucial part of this sense of past, present and future: houses were built and rebuilt, fields were created, adapted, and merged, ritual sites were constructed and reconstructed, perhaps with different meanings over time. All these things helped to create a past and therefore a history.

Bronze Age societies created and partook of that history, just as other past societies have done. Individuals may only have had a lifespan less than half ours; the societies in which they lived lasted much longer. Their societies changed over time, though by our modern standards relatively slowly; but change they did.

In any case there is no need for despair if we cannot write a history of the Bronze Age world. We can say so much about the communities, their interactions, their lives and their deaths, from the abundant data that is now available, and the increasingly sophisticated and penetrating ways of analysing it. The Bronze Age world was not our world, nor can we experience it, even indirectly. We may not have texts to aid us in our understanding of prehistoric Europe, but we do have material that does not lie: material culture. Provided we approach the data carefully, and with respect, Bronze Age societies can come alive for us. 